\title{
BACTERIAL LOADS IN SHRIMP AND FISH HATCHERY ENVIRONMENTS OF BANGLADESH
}

\author{
MD. ABDUR RAZZAK HASAN, MD. INJA-MAMUN HAQUE, ANWAR HOSSAIN, \\ MAHMUD HASAN AND MOHAMMAD SHAMSUR RAHMAN* \\ Department of Fisheries, Faculty of Biological Sciences, University of Dhaka, \\ Dhaka 1000, Bangladesh
}

\begin{abstract}
Artemia hatching tank of Cox's Bazar hatchery had similar total bacterial build up (2.59 $\pm 0.10 \times 10^{7} \mathrm{cfu} / \mathrm{g}$ ) in the water sampled and in the shrimp post larvae (PL) sampled at stage 10 and $12\left(2.37 \pm 0.11 \times 10^{7} \mathrm{cfu} / \mathrm{g}\right.$ and $2.42 \pm 0.10 \times 10^{7} \mathrm{cfu} / \mathrm{g}$, respectively). In MA plate, no significant differences was observed in the bacterial count of these samples. Similar result was observed for the total presumptive vibrio count in TCBS plates ranging from $3.8 \pm 0.60 \times 10^{3} \mathrm{cfu} / \mathrm{g}$ to $1.62 \pm 0.50 \times 10^{3} \mathrm{cfu} / \mathrm{g}$. Total bacterial load $\left(7.5 \pm 0.11 \times 10^{7}\right)$ measured in the water sampled from 25 day old fry rearing pond of tilapia from Mymensingh Hatchery, was similar to that of 33 day old fry $\left(8.6 \pm .66 \times 10^{7}\right)$. The bacterial density found in the $25\left(1.6 \pm 0.50 \times 10^{7}\right), 28\left(3.12 \pm 0.14 \times 10^{7}\right)$ and 40 day old fry $\left(6.46 \pm 1.52 \times 10^{6}\right)$ samples was similar but significantly different from the sample of 33 day old fry and the water sample of the pond of 25 day old fry. In TCBS plate, bacterial abundance detected in the samples across all four age groups was similar (25 day old fry: $4.21 \pm 3.79 \times 10^{3} ; 28$ day old fry: $4.90 \pm 3.50 \times 10^{3} ; 33$ day old fry: $1.08 \pm$ $0.12 \times 10^{3} ; 40$ day old fry: $\left.7.04 \pm 2.08 \times 10^{3}\right)$. In finfish hatchery ofBogra, the overall bacterial build up $\left(2.03 \pm 0.31 \times 10^{8}\right)$ found in the samples of zeol fish fry in NA plate was significantly higher than that of thecorresponding rearing pond water $\left(2.11 \pm 0.459 \times 10^{7}\right)$ and the water of the live food rearing tank $\left(8.43 \pm 0.57 \times 10^{6}\right)$. Similar to that, TCBS plates had 2.3-, and 5.09-folds higher bacterial load $\left(1.08 \pm 0.25 \times 10^{3}\right)$ in the samples of fish fry than in the samples of the corresponding water samples and water samples of the live food rearing tank, respectively $\left(4.70 \pm \mathrm{w} 1.67 \times 10^{2}\right.$ and $\left.2.12 \pm 0.28 \times 10^{2}\right)$.
\end{abstract}

Key words: Bacterial loads, Vibrio, Shrimp hatchery, Fish hatchery

\section{Introduction}

Bacteriology is one of the most important areas determining the pond/hatchery dynamics and health and hygiene of fish farming system. The present day fish farming is based on nutritive feeds in addition to other management practices. Consequently, the bacteriology of cultured fishes in the tropics is receiving greater attention since some species of bacteria associated with fish cause diseases under stress condition. Fish is in direct contact with microflora in the environment and the opportunistic pathogens already present in the water invade the host under stress (Rekhari et al. 2014).

Recent interest on microbial study of aquaculture products also increases the importance of knowledge of microflora associated with fish (Reilly and Kaferstein 1997). Bacterial

\footnotetext{
${ }^{*}$ Corresponding author
} 
load and bacterial type in shrimp and fish ponds have received attention of researchers (Otta et al. 1999, Al-Harvi and Uddin 2007) but little literature is available on the bacterial flora in cultivable fish (Cahill 1990 and Sugita 2006). There is limited literature available on microbiological studies in fresh water fish and the culture environment. The information will be of great value in determining whether there is need to control bacteriological parameters in farming system.

Bacterial flora on fish reflects the aquatic environment which affects the quality and storage life of fishery products (Shewan 1976). It has been repeatedly suggested that the bacterial flora of fish might reflect the bacteriological conditions of the water and a potential indicator of pollution. Therefore, to understand the vulnerability and quality of the hatchery environments and to detect the prevalence of Vibrio spp., both total bacterial count and total presumptive Vibrio count was taken for the samples using Nutrient Agar (NA) and Thiosulfate Citrate Bile Salts Sucrose (TCBS) media, where the latter is selective for Vibrio like species. Marine Agar (MA) is used only for the shrimp hatchery samples to understand the overall density of the marine micro flora.

According to a World Bank report that estimated the global losses due to shrimp diseases are around US\$ 3 billion (Lundin et al. 2006). Fisheries in both saline water and freshwater are becoming increasingly vulnerable to bacterial infection due to the ease with which pathogens are transmitted in aquaculture. Nevertheless disease outbreaks are being increasingly recognized as a noteworthy impediment on aquaculture production and trade, affecting the economic development of Bangladesh like many other countries. Various infectious diseases caused by bacteria, virus and protozoa are now a primary concern in aquaculture (Rahman et al. 2014). Disease outbreak is often directly related with the bacterial density in a particular environment. However, there is no bacteriologicalstudy in the hatchery environment of Bangladesh.

In the present study, three different types of hatcheries (shrimp, tilapia and finfish) were investigated with equal emphasis considering their pervasiveness in Bangladesh. The objective of the present study was to assess the bacteriological status of the sampled shrimp and fish hatchery environments of Bangladesh, in order to comment on the possibility of future disease outbreak.

\section{Materials and Methods}

Sampling: A total of 42 samples, 16 of which were from coastal shrimp hatcheries, 14 from tilapia hatchery and 12 were from freshwater fish hatcheries, was randomly collected and examined (Table 1). The sampling was done during the period of June 2015 to August 2015. The samples usedwere shrimp (Penaeus monodon) post-larvae (PL), brine shrimp nauplii- Artemia spp. (live feed), fry of tilapia (Oreochromis niloticus), Asisan stinging catfish (Heteropneustes fossilis), walking catfish (Clarias batrachus) and striped catfish (Pangasianodon hypophthalmus), and the culture-water. Samples were collected from three different districts of Bangladesh- Cox's Bazar, Mymensingh and Bogra. All the laboratory investigations were carried out in the Aquatic Laboratory of Department of Fisheries, University of Dhaka. The samples were kept in icebox maintaining temperature at $4^{0} \mathrm{C}$ and then transferred to the laboratory. All samples were collected following the 
method of American Public Health Association (APHA 1998). Fry and PL samples were aseptically grinded in a mortar and blended with physiological saline $(0.85 \% \mathrm{NaCl})$. All blended samples were kept in a distance to reduce cross contamination.

Bacterial enumeration: Serial dilution technique (APHA 1998) was used for counting the bacterial colonies. $100 \mu \mathrm{L}$ blended suspension was mixed with $900 \mu \mathrm{L}$ of sterile saline water in an eppendorf using vortex machine. This process was repeated three more times to get the final $4^{\text {th }}$ dilution from which $100 \mu \mathrm{L}$ suspension was spread in NA plate and then the plates were kept at $37^{\circ} \mathrm{C}$ for 24 hours in the incubator. Bacterial colonies grown in the NA media were counted.The same procedure was followed for total bacterial count in MA Plates.

Table 1. List of samples randomly collected from the hatcheries of Cox's Bazar, Mymensingh and Bogra districts of Bangladesh

\begin{tabular}{|c|c|c|c|c|c|}
\hline \multicolumn{2}{|c|}{ Shrimp hatchery of Cox's Bazar } & \multicolumn{2}{|c|}{$\begin{array}{l}\text { Tilapia hatchery of } \\
\text { Mymensingh }\end{array}$} & \multicolumn{2}{|c|}{ Finfish hatchery of Bogra } \\
\hline $\begin{array}{l}\text { Sample } \\
\text { ID }\end{array}$ & Sample & $\begin{array}{l}\text { Sample } \\
\text { ID }\end{array}$ & Sample & $\begin{array}{l}\text { Sample } \\
\text { ID }\end{array}$ & Sample \\
\hline $\mathrm{C} 1$ & $\begin{array}{l}\text { Artemianauplii from } \\
\text { Tank } 1\end{array}$ & M1 & $\begin{array}{l}\text { Tilapia fry, } 40 \\
\text { days, Big size }\end{array}$ & B1 & $\begin{array}{l}\text { Walking catfish fry, } 5 \\
\text { days }\end{array}$ \\
\hline $\mathrm{C} 2$ & $\begin{array}{l}\text { Artemianauplii from } \\
\text { Tank } 2\end{array}$ & M2 & $\begin{array}{l}\text { Tilapia fry, } 40 \\
\text { days, Medium }\end{array}$ & B2 & $\begin{array}{l}\text { Water from the tank of } \\
\text { walking catfish, } 5 \text { days }\end{array}$ \\
\hline $\mathrm{C} 3$ & $\begin{array}{l}\text { Shrimp PL of } 10 \text { days, } \\
\text { Tank } 1\end{array}$ & M3 & $\begin{array}{l}\text { Tilapia fry, } 40 \\
\text { days, Small size }\end{array}$ & B3 & $\begin{array}{l}\text { Water from live feed } \\
\text { pond }\end{array}$ \\
\hline $\mathrm{C} 4$ & $\begin{array}{l}\text { Water from PL(10) } \\
\text { Tank } 1\end{array}$ & M4 & $\begin{array}{l}\text { Tilapia fry, } 25 \\
\text { days }\end{array}$ & B4 & $\begin{array}{l}\text { Stinging catfish fry, } 6 \\
\text { days }\end{array}$ \\
\hline $\mathrm{C} 5$ & $\begin{array}{l}\text { Shrimp PL of } 10 \text { days, } \\
\text { Tank } 2\end{array}$ & M5 & $\begin{array}{l}\text { Tilapia fry, } 25 \\
\text { days }\end{array}$ & B5 & $\begin{array}{l}\text { Water from the tank of } \\
\text { stinging catfish, 6days }\end{array}$ \\
\hline C6 & $\begin{array}{l}\text { Water from PL(10) } \\
\text { Tank } 2\end{array}$ & M6 & $\begin{array}{l}\text { Tilapia fry, } \\
\text { 25days }\end{array}$ & B6 & $\begin{array}{l}\text { Walking catfish fry, } 6 \\
\text { days }\end{array}$ \\
\hline $\mathrm{C} 7$ & Shrimp PL of 12 days & M7 & $\begin{array}{l}\text { Tilapia fry, } \\
\text { 28days }\end{array}$ & B7 & $\begin{array}{l}\text { Water from the tank of } \\
\text { walking catfish, } 6 \text { days }\end{array}$ \\
\hline $\mathrm{C} 8$ & $\begin{array}{l}\text { Water from PL(12) } \\
\text { Tank }\end{array}$ & M8 & $\begin{array}{l}\text { Tilapia fry, } \\
\text { 28days }\end{array}$ & B8 & $\begin{array}{l}\text { Striped catfish fry, } 5 \\
\text { days }\end{array}$ \\
\hline C9 & $\begin{array}{l}\text { Artemianauplii from } \\
\text { Tank } 1\end{array}$ & M9 & $\begin{array}{l}\text { Tilapia fry, } \\
\text { 28days }\end{array}$ & B9 & $\begin{array}{l}\text { Water from the tank of } \\
\text { striped catfish, } 5 \text { days }\end{array}$ \\
\hline $\mathrm{C} 10$ & $\begin{array}{l}\text { Artemianauplii from } \\
\text { Tank } 2\end{array}$ & M10 & $\begin{array}{l}\text { Tilapia fry, } \\
\text { 33days }\end{array}$ & B10 & $\begin{array}{l}\text { Striped catfish fry, } 1 \\
\text { day }\end{array}$ \\
\hline $\mathrm{C} 11$ & $\begin{array}{l}\text { Shrimp PL of } 8 \text { days } \\
\text { from PL (8) Tank }\end{array}$ & M11 & $\begin{array}{l}\text { Tilapia fry, } \\
\text { 33days }\end{array}$ & B11 & $\begin{array}{l}\text { Water from the tank of } \\
\text { striped catfish, } 1 \text { day }\end{array}$ \\
\hline $\mathrm{C} 12$ & $\begin{array}{l}\text { Water from PL(8) } \\
\text { Tank }\end{array}$ & M12 & $\begin{array}{l}\text { Tilapia fry, } \\
\text { 33days }\end{array}$ & B12 & $\begin{array}{l}\text { Water from live feed } \\
\text { pond }\end{array}$ \\
\hline $\mathrm{C} 13$ & $\begin{array}{l}\text { Shrimp PL of } 12 \\
\text { daysTank2 }\end{array}$ & M13 & $\begin{array}{l}\text { Water from } \\
\text { Tilapia hapa }\end{array}$ & & \\
\hline $\mathrm{C} 14$ & $\begin{array}{l}\text { Water from PL(12) } \\
\text { Tank } 2\end{array}$ & M14 & $\begin{array}{l}\text { Water from } \\
\text { Tilapia hapa }\end{array}$ & & \\
\hline $\mathrm{C} 15$ & $\begin{array}{l}\text { Shrimp PL of } 10 \text { days, } \\
\text { Tank } 3\end{array}$ & & & & \\
\hline $\mathrm{C} 16$ & $\begin{array}{l}\text { Water from PL(10) } \\
\text { Tank } 3\end{array}$ & & & & \\
\hline
\end{tabular}


$100 \mu \mathrm{L}$ blended raw suspension from each sample was spread in TCBS plate and were kept at $37^{\circ} \mathrm{C}$ for 24 hours. Then the Vibrio colony count was done.

Statistical analysis: Bacterial density data were transformed into natural log before statistical analysis. The means of bacterial load were compared using ANOVA followed by Tukey's post hoc for multiple comparisons. Statistical software SPSS version 20.0 was used to analyze the data with the level of significance at $p<0.05$. For plotting the graphs Microsoft Excel (2010) was used.

\section{Results and Discussion}

Bacterial density (cfu/g) found in shrimp hatchery of Cox's Bazar in Nutrient Agar (NA) Plate:The bacterial load $\left(2.59 \pm 0.10 \times 10^{7}\right)$ detected in the water sampled from Artemia hatching tank of shrimp hatcheryis similar to the density observed in the shrimp postlarvae (PL) sampled at stage 10 and $12\left(2.37 \pm 0.11 \times 10^{7}\right.$ and $2.42 \pm 0.10 \times 10^{7}$ respectively; (Fig. 1). However, bacterial load determined from the samples of water corresponding to the stages of PL were similar but different from the samples of Artemia tank and PL stages of 10 and 12 . But the bacterial load $\left(1.38 \pm 0.19 \times 10^{7}\right)$ found in the PL 8 stage was different from the load sampled from PL tank water and other PL stages.

Similar bacterial density between Artemiatank and shrimp PL as observed in this study in NA plate could be due to the use of Artemia nauplii and shrimp PL as the host organisms. Lower density of total bacteria in the water of PL rearing tank in comparison with the PL, supports the findings of Raoand Surendran(2013) and denotes the absence of host organisms. Progressively higher density of total bacterial abundance in the shrimp PL of stages from 8 to 12 could be due to size variation.

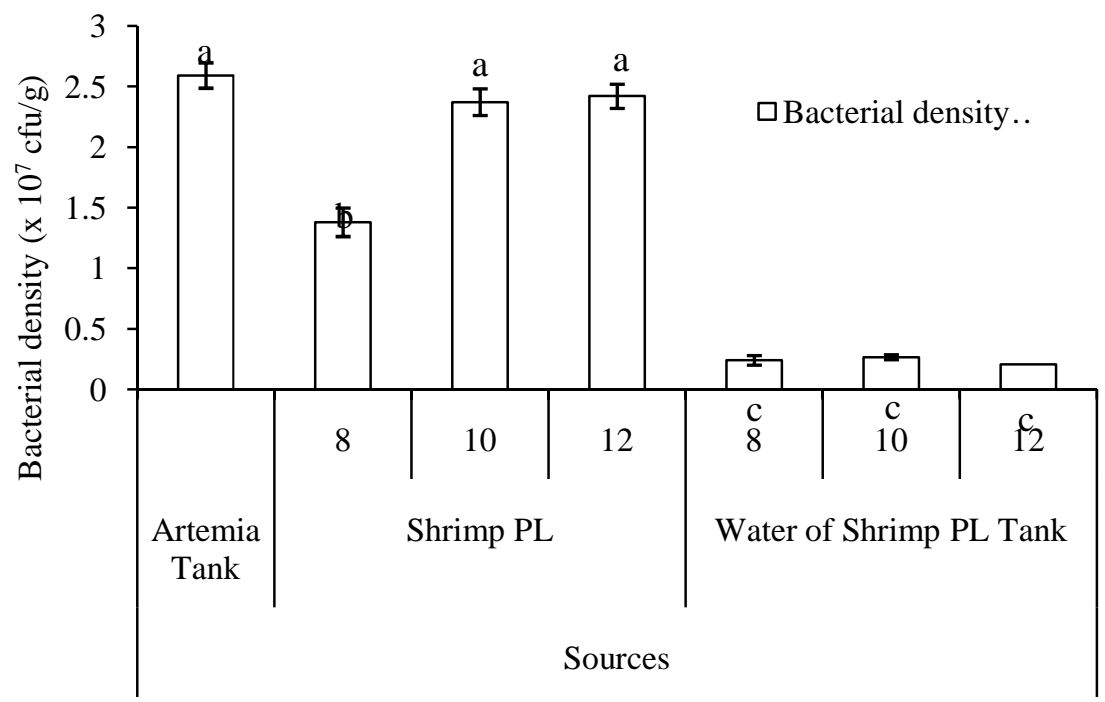

Fig. 1. Bacterial density (cfu/g) found in shrimp hatchery of Cox's Bazar in Nutrient Agar (NA) Plate. Bars (mean \pm 1 SEM) with different letters are significantly different (ANOVA, HSD; $\mathrm{P}<0.05)$. 
Bacterial density (cfu/g) found in shrimp hatchery of Cox's Bazar in Marine Agar (MA) Plate: In MA plate, no significant differences was observed in the bacterial count detected in water sampled from Artemia tank and in the PL and corresponding water of PL rearing tank water samples (Fig. 2).

Only few thousands ( $<5000 \mathrm{cfu} / \mathrm{g}$ ) bacterial abundance in MA plate across all samples of Artemiatank, shrimp PL and the water of the PL rearing tank could have resulted since the growth was observed in marine selective media. Therefore, the growth was similar across all samples.

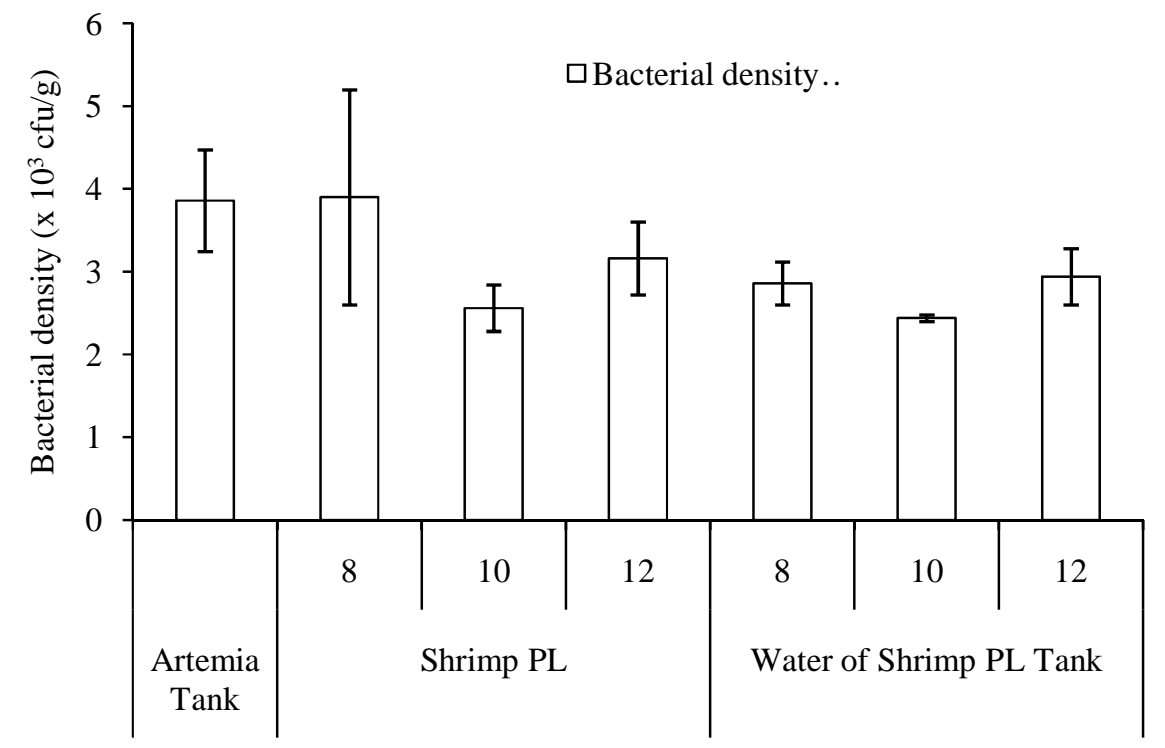

Fig. 2. Bacterial density (cfu/g) found in Shrimp hatchery of Cox's Bazar in Marine Agar (MA) Plate. Bars (mean \pm 1 SEM) with no letters indicate no significant difference (ANOVA, HSD; $\mathrm{P}<0.05)$.

Bacterial density (cfu/g) found in shrimp hatchery of Cox's Bazar in TCBS Agar Plate: Similar to MA plate, TCBS plates also did not result in any significantly different bacterial density in the water sampled from Artemia tank, in the PL and corresponding water sampled from different PL rearing tanks (Fig. 3).

In TCBS plate, bacterial density was found to range between 1620 and $3800 \mathrm{cfu} / \mathrm{g}$ which also indicates selective growth of Vibrio spp. But shrimp PL had greater mean loads of presumptive Vibrio than in their surrounding water body which is similar with the previous reports (Otta et al. 2001). 


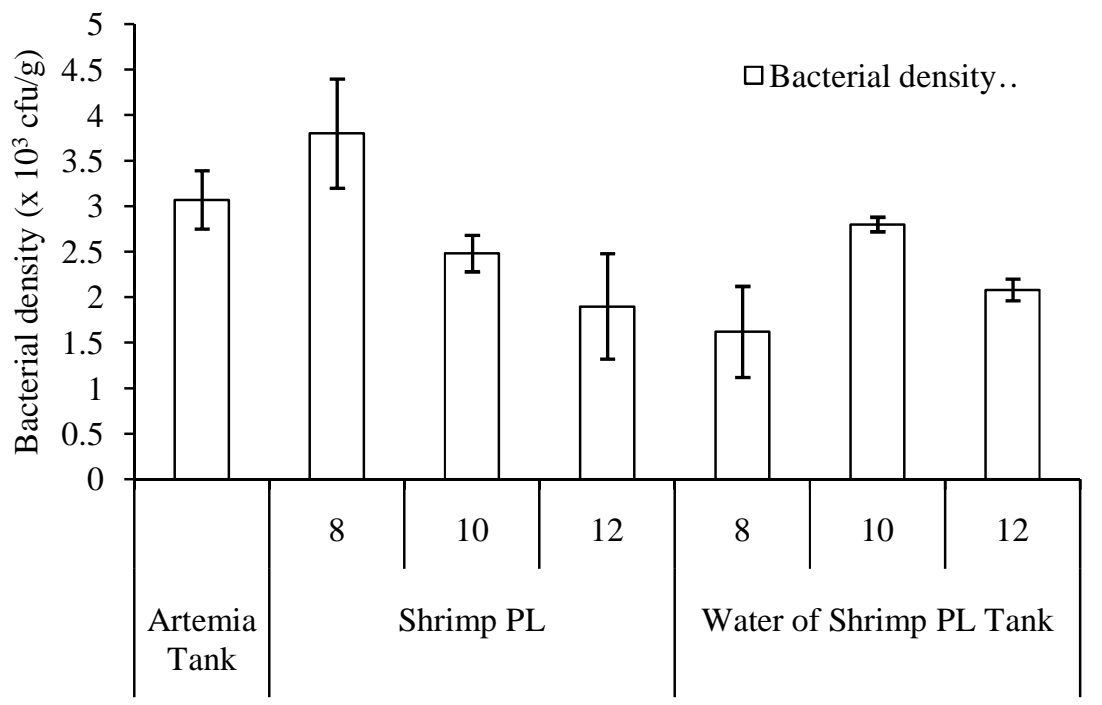

Fig. 3. Bacterial density (cfu/g) found in Shrimp hatchery of Cox's Bazar in TCBS Agar Plate. Bars (mean \pm 1 SEM) with no letters denote no significant difference (ANOVA, HSD; $\mathrm{P}<0.05)$.

Bacterial density (cfu/g) found in Tilapia Hatchery of Mymensingh in Nutrient Agar (NA) Plate: In NA plate, the bacterial load $\left(7.5 \pm 0.11 \times 10^{7}\right)$ measured in the water sampled from 25 day old fry rearing pond of tilapia was similar to that of 33 day old fry $\left(8.6 \pm .66 \times 10^{7}\right.$; Fig. 4a). The bacterial density found in the $25\left(1.6 \pm 0.50 \times 10^{7}\right), 28(3.12$ $\left.\pm 0.14 \times 10^{7}\right)$ and 40 day old fry $\left(6.46 \pm 1.52 \times 10^{6}\right)$ samples were similar but significantly different from the sample of 33 day old fry and the water sample of the pond of 25 day old fry.

Very high bacterial abundance $\left(7.55 \pm 0.11 \times 10^{7}\right)$ as found in the water of the 25 day old tilapia fry rearing pond could have resulted due to anthropogenic contamination. Interestingly, 40 day old tilapia fry had 10 times lower bacterial build up than in the 33 day old tilapia fry. The reason responsible behind this variation in the total count of bacteria in NA plate is unknown. Typically smaller fish should have lower bacterial load compared to the bigger ones.

Bacterial density (cfu/g) found in Tilapia Hatchery of Mymensingh in TCBS Plate: In TCBS plate, bacterial abundance detected in the samples across all four age groups was similar ( 25 day old fry: $4.21 \pm 3.79 \times 10^{3} ; 28$ day old fry: $4.90 \pm 3.50 \times 10^{3} ; 33$ day old fry: $1.08 \pm 0.12 \times 10^{3} ; 40$ day old fry: $7.04 \pm 2.08 \times 10^{3}$; Fig. 4 b). No bacterial count was found in the water sampled from 25 day old fry rearing pond. 


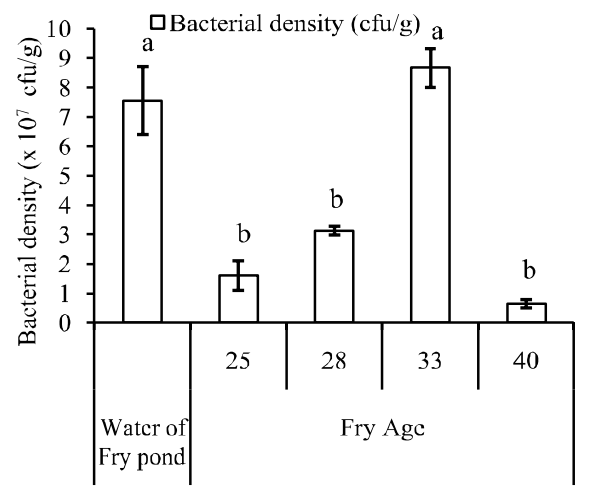

(a)

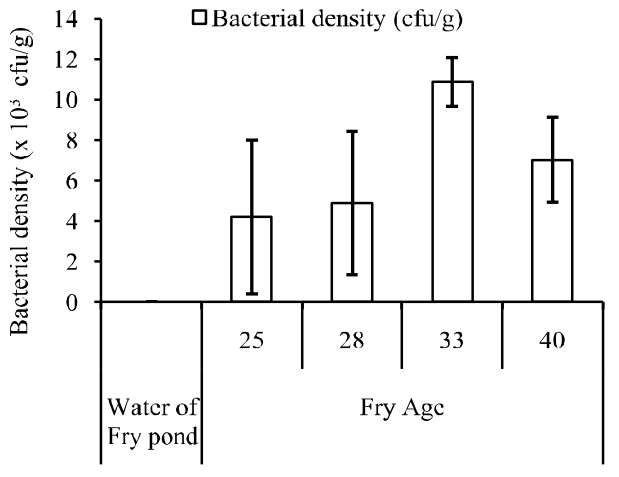

(b)

Fig. 4. Bacterial density (cfu/g) found in the tilapia fry rearing pond water and in the fries of 25 , 28, 33 and 40 days old in Tilapia Hatchery, Mymensingh in (a) NA plate and (b) TCBS plate. Bars (mean $\pm 1 \mathrm{SEM}$ ) with different letters are significantly different (ANOVA, HSD; $\mathrm{P}<0.05)$.

In TCBS plate, no growth of any bacteria denotes absence of Vibrio spp. in 25 day old tilapia fry rearing pond water. This absence of Vibrio in the fry rearing pond water indicates no contamination from anthropogenic sources as well as denotes the quality level of the fry feed. However, tilapia fry aged from 25-40 day old had similar Vibrio growth that indicates the possibility of later contamination from unknown sources. Even environmental parameters such as temperature, salinity, $\mathrm{pH}$ and dissolved oxygen play a foremost part in the distribution of bacteria (Palaniappan 1982 and Parvez et al. 2015).

Overall Bacterial density (cfu/g) found in finfish hatchery of Bogra in Nutrient Agar (NA) Plate:

The overall bacterial build up $\left(2.03 \pm 0.31 \times 10^{8}\right)$ found in the samples of fish fry in NA plate was significantly higher than that of the corresponding rearing pond water $(2.11 \pm$ $\left.0.459 \times 10^{7}\right)$ and the water of the live food rearing tank ( $8.43 \pm 0.57 \times 10^{6}$; Fig. 5a).

Nearly 10 and 20 times higher total bacterial abundance in the fry of striped catfish, walking catfish and stinging catfish compared to that of live food rearing tank water and the water of fry rearing ponds in NA plate could also be responsible for the established fact that fish body carries higher microbial organisms than that of surrounding water body. This might be due to the high organic load in the incoming water (Otta et al. 2001). The same reasons could also be responsible for the presumptive Vibrio spp. growth in TCBS plates of the corresponding samples. 


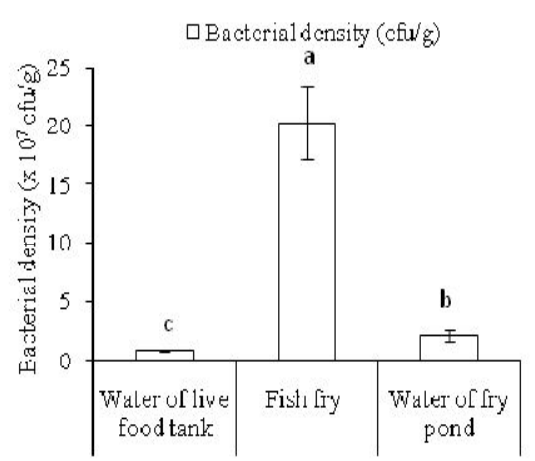

(a)

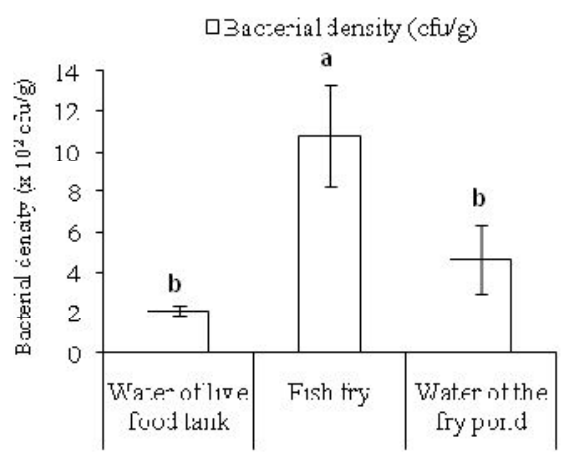

(b)

Fig. 5. Overall bacterial load (cfu/g) detected in (a) NA plate and (b) TCBS plate from the samples of water of the live food tank, fry of fishes (stinging catfish, walking catfish, and striped catfish) and water of the fry rearing pond of finfish hatchery of Bogra. Bars (mean \pm 1 SEM) with different letters indicate significant difference (ANOVA, HSD; $\mathrm{P}<0.05$ ).

Overall Bacterial density ( $\mathrm{cfu} / \mathrm{g}$ ) found in finfish hatchery ofBogra in TCBS plate: Similar to the overall bacterial density found in NA plate, TCBS plates had 2.3-, and 5.09 -folds higher bacterial load $\left(1.08 \pm 0.25 \times 10^{3}\right)$ in the samples of fish fry than in the samples of the corresponding water samples and water samples of the live food rearing tank, respectively $\left(4.70 \pm 1.67 \times 10^{2}\right.$ and $2.12 \pm 0.28 \times 10^{2}$; Fig. 5b).

Bacterial density (cfu/g) found in fish fry offinfish hatcheryofBograin NA Plate: In NA plate, the bacterial load found in stinging catfish fry $\left(2.77 \pm 0.11 \times 10^{8}\right)$ samples was similar to the density of walking catfish fry $\left(2.23 \pm 0.03 \times 10^{8}\right)$ but significantly higher than in the sample of striped catfish fry $\left(1.10 \pm 0.10 \times 10^{8}\right.$; Fig.6a).

Particularly the reason of significant differences in total bacterial load in NA plate between the striped catfish fry and the near similar walking catfish and stinging catfish fry could be the discrepancy in their hardiness. The hardier the fish species the more bacterial load it may contain.

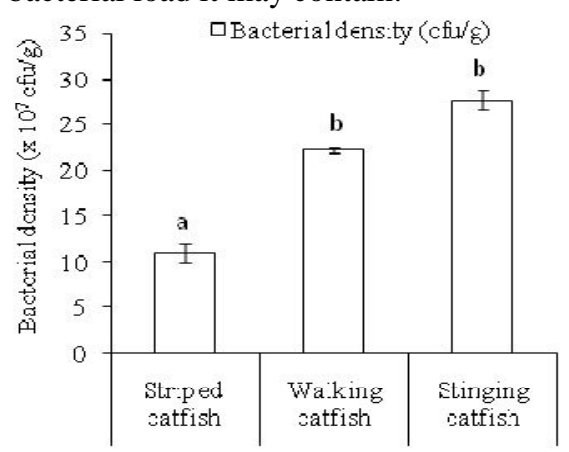

(a)

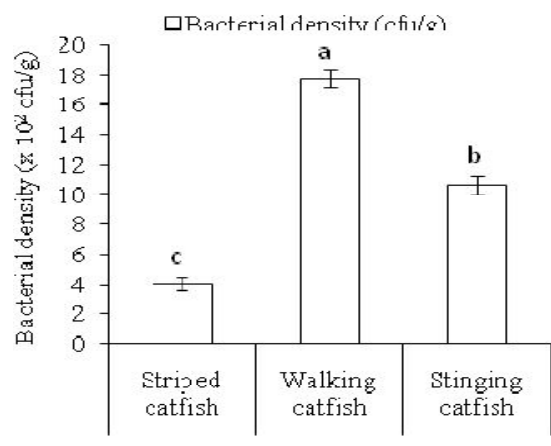

(b)

Fig. 6. Bacterial load detected in (a) NA plate and (b) TCBS plate in the samples of striped catfish, walking catfish and stinging catfish fry of finfish hatchery of Bogra. Bars (mean \pm 1 SEM) with different letters are significantly different (ANOVA, HSD; $\mathrm{P}<0.05$ ). 
Bacterial density (cfu/g) found in finfish hatchery of Bogra in TCBS Plate: In TCBS plate, while walking catfish fry had the highest density of bacteria $\left(1.78 \pm 0.06 \times 10^{3}\right)$ the lowest density $\left(4.05 \pm 0.45 \times 10^{2}\right)$ was detected in the striped catfish fry (Fig.6b). However, stinging catfish fry resulted in the bacterial build up $\left(1.60 \pm 0.06 \times 10^{3}\right)$ that was significantly lower than that of walking catfish fry but higher than did the striped catfish fry.

The statistical significant difference in the amount of Vibrio like bacteria of the striped catfish, walking catfish and stinging catfish fry samples in TCBS plate also advocates for the previously stated reason.

Bacterial density (cfu/g) found in finfish hatchery ofBogra in NA Plate: In NA plate, while water of striped catfish and stinging catfish fry rearing pond water had similar (striped catfish: $2.95 \times 10^{7} \pm 0.13 \times 10^{7}$; stinging catfish: $2.72 \times 10^{7} \pm 0.07 \times 10^{7}$ ) but significantly higher bacterial load that did walking catfish fry rearing pond water $\left(6.76 \times 10^{6} \pm 0.34 \times 10^{6} ;\right.$ Fig. $\left.7 \mathrm{a}\right)$.

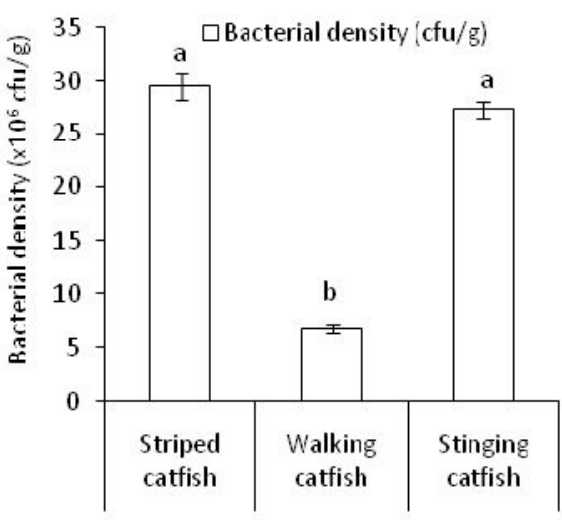

(a)

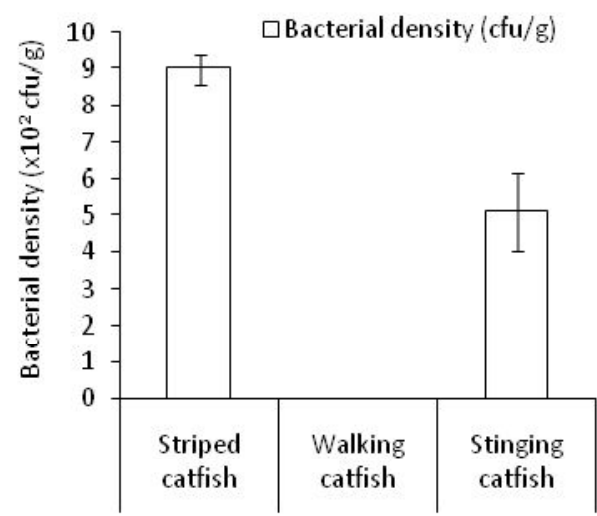

(b)

Fig. 7. Bacterial load (cfu/g) counted in (a) NA plate and (b) TCBS plate from the water samples of the corresponding striped catfish, walking catfish and stinging catfish fry rearing pond in finfish hatchery, Bogra. Bars (mean \pm 1 SEM) with different letters are significantly different (ANOVA, HSD; $\mathrm{P}<0.05$ ) and bars with no letters denote no significant difference

Bacterial density (cfu/g) found in finfish hatchery of Bogra in TCBS Plate: In TCBS plate, while the water of walking catfish fry rearing pond had no bacterial load, the stinging catfish and striped catfish fry rearing pond water had $5.10 \pm 1.10 \times 10^{2}$ and $9 \pm$ $0.04 \times 10^{2}$, respectively (Fig. $7 b$ ).

The bacterial load in NA plate of the water samples of walking catfish fry rearing pond is significantly different from the water samples striped catfish and stinging catfish fry rearing pond. Water of walking catfish fry rearing pond has lowest both TBC and TVC in NA and TCBS plates, respectively. The reason behind this variation perhaps lies on the 
treatments applied and the quality of the water of the corresponding fish fry rearing ponds. However, the mean total bacterial density in the fry rearing ponds exceeded the reported range of Otta et al. 2001; while the mean total presumptive Vibrio count was a bit lower than their recommended values. Better water management systems adopted by hatcheries might play important role in this respect (Rao et al. 2013).

Under stressful conditions, bacteria may become opportunistic and attack the body tissue and produce disease. The need is thus felt to monitor and regulate the bacterial parameters in the present aquaculture system where lot of management is done to enhance production. The high density of total bacteria in the fresh water hatcheries demands molecular analysis of these species to investigate the presence of potential probiotics that may use in shrimp/finfish aquaculture and of opportunistic fish or shrimp pathogens in that community.

\section{References}

Al-Harbi, A.H. and N. Uddin. 2007. Quantitative and Qualitative studies on bacterial flora of hybrid tilapia (Oreochromisniloticusx O. aureus) cultured in earthen ponds in Saudi Arabia. Aquacult.Res. 34(1):431-448.

APHA, 1998. Standard Methods for the Examination of Water and Wastewater. 20th edn. American Public Health Association, Wastingingcatfishton DC, 1325 pp.

Bondad-Reantaso, M.G., R.P. Subasinghe, J.R. Arthur, K. Ogawa, S. Chinabut, R. Adlard, Z. Tan and M. Shariff. 2005. Disease and health management in Asian aquaculture. Vet. Parasitol. 132(3-4): 249-272.

Cahill, M.M. 1990. Bacterial flora of Fishes: A review. Microb. Ecol. 19(1): 21-41.

Lundin, G.G. 1996. Fish health and quarantine. In: Global Attempts to Address Shrimp Disease. Marine/ Environmental Paper No. 4.P. 45. World Bank, Rome.

Otta, S.K., K. Indraniand K. Iddya. 1999. Bacterial flora associated with shrimp culture ponds growing Penaeus monodon in India. J. Aqua. Trop.14(4):309-318.

Otta, S.K., I. Karunasagar and I. Karunasagar. 2001. Bacteriological study of shrimp, PenaeusmonodonFabricius, hatcheries in India. J. Appl. Ichthyol.17(2): 59-63

Palaniappan, R. 1982. Studies on the microflora of the shrimp Penaeusindicus, Milne Edwards (crustacea, decopodes, penaedae) with reference to its digestive system.PhD Thesis, Annamalai University, India.

Parvez, M.S., M. Mohiuddin, M.N. Ahsan, S. Aktar and S. Sultana. 2015. Effect of growth promoter on the total bacterial load in Anabas testudineus culture ponds. IJRASET, 3(1): 175-179.

Rahman, S., S.N. Khan, M.N. Naser and M.M. Karim, 2014. Probiotic technology for sustainable aquaculture. In: Advances in Fisheries Research in Bangladesh (eds. M.A. Wahab, M.S. Shah, M.A.R. Hossain, B.K. Barman and M.E. Hoq). pp 83-96, Proc. of $5^{\text {th }}$ Fisheries conference and research fair 2012. Bangladesh Fisheries Research Forum, Dhaka, Bangladesh.

Rao, B.M. and P.K. Surendran. 2013. Pathogenic Vibrios in Penaeusmonodon Shrimp Hatcheries and Aquaculture Farms. Fishery Technol.50: 161 - 167. 
Reilly, A. and R. Kaferstein.1997. Food safety hazards and the application of the principles of the hazard analysis and critical control point (HACCP) system for their control in aquaculture production. Aquacult. Res. 28(10):735-752.

Rekhari, Y.C., R. Agrawal, M.D. Trakroo and H. Tiwari. 2014. Qualitative and quantitative study on bacterial flora of farm raised common carp, Cyprinuscarpio in India. African Journal of Microbiology Research, 8(11): 1125-1129.

Shewan, J.M. 1976. The bacteriology of fresh and spoiling fish and the biochemical changes induce by bacterial action. In: Proceeding of tropical institute conference on the handling, processing and marketing of tropical fish. pp. 51-66. Tropical Products Institute, London.

Sugita, H. 2006. Identification of intestinal bacteria from Japanese flounder (Paralichthysolivacens) and their ability to digest chitin. Appl. Microbiol. 43(3):116-112. 